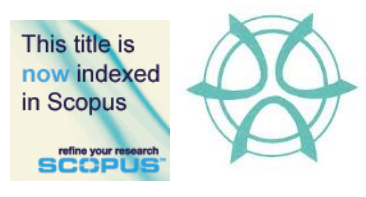

PLANNING MALAYSIA:

Journal of the Malaysian Institute of Planners

SPECIAL ISSUE V (2016), Page 1 - 12

\title{
SUSTAINABLE URBAN DEVELOPMENT THROUGH URBAN CONSOLIDATION POLICY IN SHIRAZ, IRAN
}

\author{
Mozhgan Samzadeh ${ }^{1}$, Zunaibi Abdullah ${ }^{2}$, Saari Omar $^{3}$ \& Aniza Abdul Aziz ${ }^{4}$ \\ ${ }^{1,2,3,4}$ Centre for Building, Construction \& Tropical Architecture \\ Faculty of Built Environment \\ UNIVERSITY OF MALAYA
}

\begin{abstract}
In the past few decades, cities from various parts of the world have faced with unplanned and uncontrolled physical expansion due to inappropriate policies. Among different solutions against urban sprawl, the dominant sustainable cure is the so-called 'Urban Consolidation' (UC). This paper aims to explore urban sprawl characteristics and present its cause and effect on the sustainability criteria of Shiraz city, Iran. It is confined to an exploration of population growth and physical expansion of the city. The data has been collected from governmental organizations and documents. This paper examines UC policy implementation in the inner city of Shiraz to control low-density urban sprawl. As the result, this paper discovers that the policy emphasizes on the higher density housing development in existing urban areas considering the capacity of infrastructures and facilities' availability prior to calculate housing targets to decrease the demand for Greenfield development. It concludes with a brief discussion on the challenges to achieve sustainable urban development goals in the city through UC strategies.
\end{abstract}

Keywords: Urban sprawl, sustainable development, urban consolidation policy, higher-density housing, Iran. 
Mozhgan Samzadeh, Zunaibi Abdullah, Saari Omar \& Aniza Abdul Aziz

Sustainable Urban Development through Urban Consolidation Policy in Shiraz, Iran

\section{INTRODUCTION}

\section{The Need to Tackle Rising Urban Sprawl}

Globalization, industrialization and rapid rate of population growth in the cities have become critical issues of concern to most national governments worldwide (Jiboye, 2011). Specifically, among such are; the Millennium Development Goals Summits, the 2002 world summit in Johannesburg, and the La-Havana UN (Oladunjoye, 2005) sustainable cities documentation of experience programmed among several others. In each of these summits, member nations reiterate the need for good and effective governance as a means of achieving sustainable development in the cities (Oladunjoye, 2005; UN-Habitat, 2007; UNDPI, 2008). In order to explain and justify this global issue of development, a World Bank Report in 2000 and another of the International Monetary Fund in 2006, had indicated that about 66 percent of the world's population lived in the countryside in the early 1950s; however, current estimate by the United Nations has put the world population at 6.572 billion people, of which 3 billion (about 50\%) now live within the urban areas, and by 2030, about 61 percent of the world population is projected to live in the cities; and this growth is expected to occur mainly in developing countries (United Nations, 2004; UNCHS, 2007; UNFPA, 2007; Daramola \& Ibem, 2010).

Roughly built-up areas of cities currently cover $400,000 \mathrm{~km}^{2}$ of the Earth's surface, and this number is rising quickly: Estimates of its predicted additional increase by 2030 range between $700,000 \mathrm{~km}^{2}$ (Angel et al., 2005) and $1,200,000 \mathrm{~km}^{2}$ (Seto et al., 2012). Cities in developing countries are expected to triple their built-up land area from $200,000 \mathrm{~km}^{2}$ to $600,000 \mathrm{~km}^{2}$ or more, and cities in developed countries will increase their built-up land area from 200,000 $\mathrm{km}^{2}$ to at least 500,000 $\mathrm{km}^{2}$ (United Nations Population Fund, 2007).

The process of fringe development has been observed and interpreted in the context of "Dissolution of Urban Structure" (Burdack, 2002). Blurring the urban-rural line and shifting relationship between city and countryside happened as results of dissolution of urban structure. A key term of the discourse is 'urban sprawl". "Sprawl is a result not just of population growth but also of new lifestyles that require more space" (Jaeger \& Schwick, 2014).

Rapid population growth increases the demand for residential land, housing, and urban infrastructure. The high demand for housing and limitation of urban areas increase housing prices in the inner city (Samzadeh, 2014) and as a result, people move further out of the city centre where affordable housing is available (urban sprawl). This paper aims to explore different attributes of urban sprawl and present its cause and effect on the sustainability criteria of Shiraz city to eliminate and control suburban development. The work presented in the paper is confined to an exploration of population growth and physical expansion of the city. 
PLANNING MALAYSIA

Sustainable Urban Development

\section{LITERATURE REVIEW}

\section{Urban Sprawl in Iranian Cities}

During the past one hundred years the Iranian urban fabrics have been transformed from compact traditional morphologies to less compact patterns and lower population densities. The street networks have changed from curvy streets and dead-end allies in the traditional fabrics to semi-gridiron networks in 1950s and 1960s and complete gridiron after 1980. The population densities decreased continuously during the last decades and the length of the urban trips became longer. Today for residents living in new districts, many destinations are not within the walking distances. On the other hand, the new urban planning system emphasized on motorized transportation. Thus most of the planning efforts are put on improving the quality of wide streets and highway systems, while drawing people to local centres and planning neighbourhood amenities are almost forgotten.

This paper aims at reviewing the policy and strategy, which have been taken by local government to combat urban sprawl in Shiraz city as a role model for other metropolitan cities (Mahdian, 2008). The main result that is expected is providing the planners of Iran and other countries with a basic concept for controlling urban sprawl. Bunker et al (2007) argues that the successful implementation of the local government strategies will depend on three main factors: (1) the degree to which the strategy reflects the planning issues being faced by the city, (2) whether policies and funding will support implementation of the plan, and (3) the way that councils choose to interpret and implement the plan.

\section{Urban Consolidation (UC)}

Urban consolidation is a policy measure that addresses the problem of urban sprawl (Malenic \& Han, 2015) such as, irreversible damage to ecosystems by scattered and fragmented urban development in greenfield areas (Brueckner, 2000; Burchell et al., 1998), reduction of green space (Brunner \& Cozens, 2013), increase in energy consumption by encouraging the use of private vehicles (Downs, 1999), causing traffic congestion (Ewing, 1997), air pollution (Johnson, 2001), and sometimes increase in carbon emissions (Gray et al., 2010).

Although the causes and patterns of urban sprawl in developing and developed countries are different, depending on the context in which they occur, recommended solutions are similar with some modifications. In terms of sustainability, the dominant view is still that increasing urban residential density, often called 'urban consolidation', is a universal urban sustainability solution (Birkeland, 2012). Smith (1997) defines Urban Consolidation (UC) as "the process of increasing and/or maintaining the density of housing in established residential areas in order to increase or maintain the population 
Mozhgan Samzadeh, Zunaibi Abdullah, Saari Omar \& Aniza Abdul Aziz

Sustainable Urban Development through Urban Consolidation Policy in Shiraz, Iran

densities of those areas". Buxton and Tieman (2005) also describe this phenomenon as "an intensification of built form and activity within a particular urban area". The concept of 'intensification' of urban land, caused by increased pressure on infrastructure and services, is a recurring concern accompanying urban consolidation.

UC as an affordable densification alternative strategy used around the world and defined as a "serendipitous solution to a range of pressing urban problems, including urban sprawl, car dependency and lack of affordable housing in urban areas" (Bunker et al., 2002).

One of the most important targets of UC is to increase use of infrastructure services and facilities provided in existing urban areas. This illustrates an economic profit, as it requires cost reduction on new urban infrastructure. Likewise, O'Connor et al. (1995) agree that "the underutilization of facilities in established areas as well as the 'isolation and deprivation of suburbia', are major drivers for urban consolidation". UC is considered as a method to create vibrant, accessible, and well-connected urban environments.

\section{RESEARCH APPROACH}

The adopted research approach in this paper is an applied urban research. Applied research is characterized as a policy focus approach. It means that the research is collaborative, problem oriented, and conducted to provide potential solutions to geographically bounded urban problems (Lerner \& Lasswell, 1951). The focus of this research is to review the urban consolidation policy and housing targets in Shiraz city through the Master Plan and HUD Strategies, and also examine the role of local municipal council in the process of implementation of this policy.

\section{Materials and Methodology}

The study utilized the environment statistical data, surveys and urban plans released by the housing and urban development organization, municipality and central statistical office of Shiraz city. Urban development plans have been respectively classified for the last two centuries to study effective factors on urban sprawl. Statistical data are collected from the 20 years' knowledge of the study area. The sixth municipal council in Shiraz city has been considered as a role model for other municipal councils in terms of implementation of urban consolidation strategies to control urban sprawl through building higher density housing in existing urban areas. 
PLANNING MALAYSIA

Sustainable Urban Development

\section{THE CASE STUDY - SHIRAZ}

\section{Urban Sprawl in Shiraz}

Shiraz is located on latitude $29^{\circ} 33^{\prime}$ North and longitude $52^{\circ} 36^{\prime}$ East. It is the capital city of Fars province and the fifth most populated city in Iran that is confronted with the problems created by the clashes between low density and urban sprawl. According to the last official census in 2006, Shiraz population has increased enormously to 1,312,146 from 170,656 in 1956.

When the land use for the average resident increases, it is named Per Capita Sprawl and it causes the urbanization of surrounding rural land. The land used per person is the total land area divided by the total number of people. This is the inverse of population density, which is the number of people per unit area of land. When per capita land consumption goes up, density goes down; when per capita land consumption goes down, density goes up (Movahed, 2008). Table 1 shows per capita land consumption of Shiraz from 1921 to 2006.

Table 1: Shiraz per capita land consumption from 1921 to 2004

\begin{tabular}{cc}
\hline Year & P.C.L consumption $(\mathbf{m} / \mathbf{p})$ \\
\hline 1921 & About 47 \\
1971 & 127 \\
1991 & 152.8 \\
2004 & 151.7 \\
\hline
\end{tabular}

Source: Shiraz Central Statistical Office

According to statistics data, Shiraz has expanded by 46 times since 1921 while the population has risen by only 15 times. Therefore, the city has encountered with urban sprawl. The growth of Shiraz city in recent 80 years has occupied on former agricultural land and rural areas specially, agricultural lands which have been ideal for its expansion. It has displaced agricultural activity to less productive areas (Movahed, 2008). Considering physical development of Shiraz to the agricultural realm, the need to take preventative measures in terms of preserving natural spaces and available potential resources is essential.

\section{Evolving Approaches to Urban Consolidation Policy in Shiraz}

Many gardens of Shiraz began to vanish in the past 30 years. These sites have become highly attractive for new residential and commercial developments (Figure 1). During much of the twentieth century, Shiraz urban form mainly consisted of low-density separate houses or single-family detached homes (Master Plan, 2007). Human population growth, migration, and increasing private automobile ownership are the most important factors forming urban development in Shiraz. 
Mozhgan Samzadeh, Zunaibi Abdullah, Saari Omar \& Aniza Abdul Aziz

Sustainable Urban Development through Urban Consolidation Policy in Shiraz, Iran

Although planning policy in the 1980's recognized the need for more compact development, low-density housing development continued as the preferred form of housing. The prevailing tendency was to eliminate residential development from larger centres in order to make ideal urban environments (MPO, 2007).

In 1990's, the Management and Planning Organization required municipal councils to prepare Residential Development Strategies to accommodate additional dwellings in existing urban areas (MPO, 2007). This heralded the start of a focus on residential development in city centres with good accessibility. "A more prescriptive approach to the location of higher density forms with the explicit promotion of development around key transport nodes and urban centres" (Bunker et al., 2002). The focus on higher density housing in city centres has intensified, and become the main concern of the Master Plan Housing Strategy.
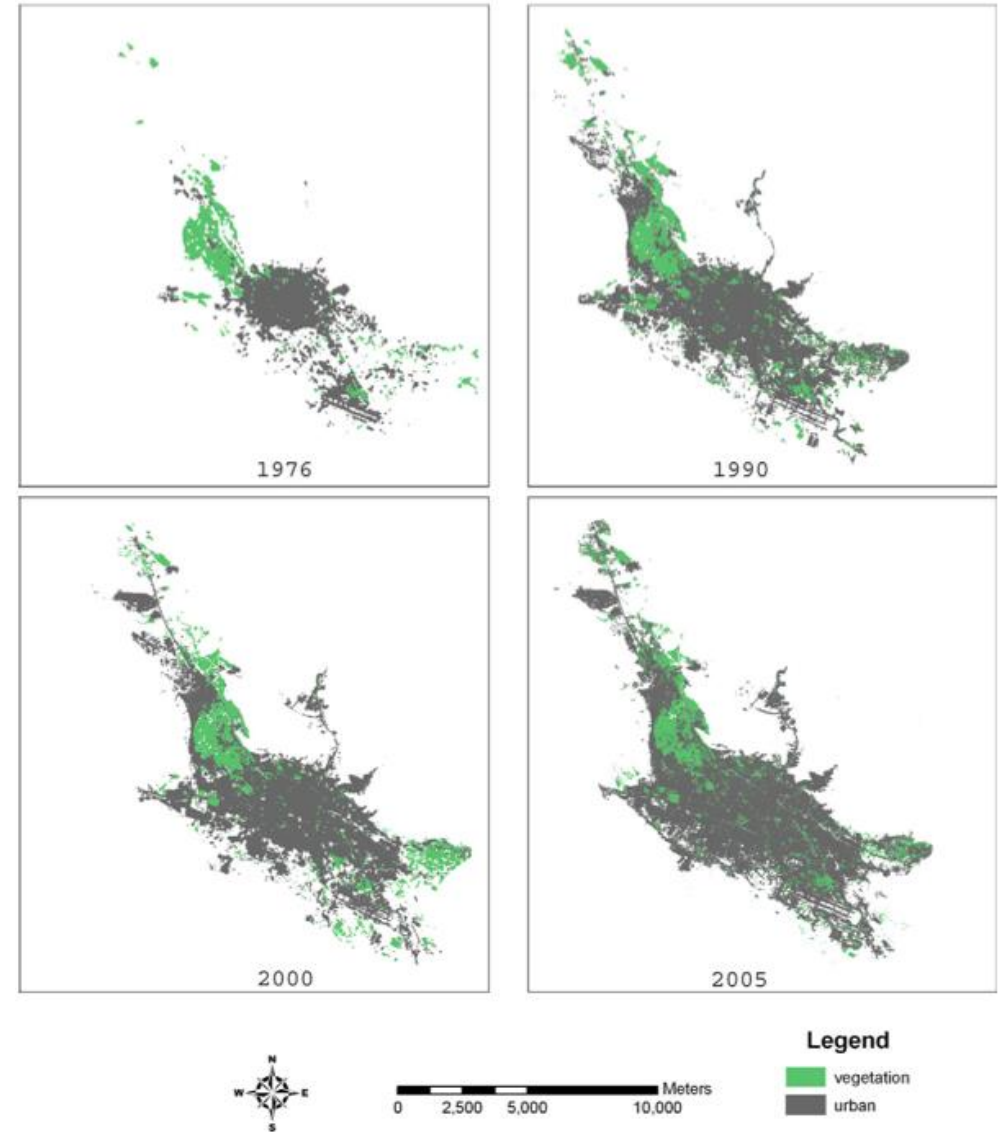

Figure 1: Urban growth of Shiraz 1976 - 2005

Source: (Sarvestani et al., 2011) 
PLANNING MALAYSIA

Sustainable Urban Development

\section{RESULTS}

\section{Shiraz Master Plan}

The latest Master Plan [Detailed Plan Review] of Shiraz as titled "The Guide to Urban Development in Shiraz City", aimed at achieving the socio-environmental and economic policy that will guide urban development in Shiraz for the next 10 years [2007-2017]. The Master Plan Housing Strategy as an integral part of planning policy illustrates the housing challenges that will be encountered, as the Shiraz population is estimated at 1.65 million over the next 10 years (MPO, 2007). The Housing Strategy is defined as "the principal planning document outlining the implementation of the policy of urban consolidation across the city" (Mahdian, 2008). The key objectives for new housing development in Shiraz are:

1. Implementation of inner city development strategies through the higher density housing pattern

2. Selecting suitable sites for higher density housing appropriate with the level of demand, capacity of infrastructures, transport network, services, and role of the area in the region

3. Plan for higher density housing near 'mixed-use' areas

4. Renew local centres

5. Improve housing affordability

6. Improve the quality of new development and urban renewal (MPO, 2007).

The housing strategy aims to reinforce the UC policy through providing higher density housing in existing urban areas of Shiraz city to accommodate 244,000 new dwellings by 2021 (MPO, 2007). Municipal councils carry out this goal through implementation of housing targets within existing urban areas. The key purpose of this strategy is to avoid housing development on Greenfield sites and to deal with urban sprawl problems.

\section{Housing and Urban Development (HUD) Strategies}

The Housing and Urban Development organization published Housing Development Strategies for eight municipal districts of Shiraz city in 2008 in line with the rules, regulation, and goals of Master Plan Strategy. These strategies encourage local municipal councils to get involved in this important initiative: 'future housing development to accommodate additional dwellings must be concentrated in and around city centres, where access to core services and facilities by individuals through public transport, walking, and cycling is locally available'. The 'Proposed urban physical divisions of Shiraz city set by HUD, as a key focus enabled municipalities to monitor the potential development of lands in urban areas to accommodate additional dwellings (Table 2). 
Mozhgan Samzadeh, Zunaibi Abdullah, Saari Omar \& Aniza Abdul Aziz

Sustainable Urban Development through Urban Consolidation Policy in Shiraz, Iran

HUD Strategies emphasize the importance of city centres' classification within the municipal districts of Shiraz city, based on types of shopping centres, medical facilities, recreational facilities, and public transportation available (Table 3). The hierarchy of city centres to determine the housing targets. A "major centre" is described as a centre with a radius of 1,000 meters, and estimated to accommodate 13,500-18,000 housings (The HUD Strategies, 2008).

All Major centres are supposed to have an equal level of services, recreational facilities, and public transportation. In order to accommodate additional housings for 244,000 new dwellings in urban areas of Shiraz city, the MPO provides the HUD Strategies to facilitate achieving the housing targets between municipal councils. These Strategies are the outcome of discussion, agreement, and cooperation between provincial and municipal offices.

Table 2: Proposed urban physical divisions of Shiraz city

\begin{tabular}{|c|c|c|c|c|c|c|}
\hline Divisions & & & & & & \\
\hline Housing unit & $\begin{array}{c}\text { Housing } \\
\text { unit }\end{array}$ & & & & & \\
\hline $\begin{array}{l}\text { Housing } \\
\text { complex }\end{array}$ & $90-200$ & $\begin{array}{l}\text { Housing } \\
\text { complex }\end{array}$ & & & & \\
\hline Neighbourhood & $400-600$ & $3-5$ & Neighbourhood & & & \\
\hline District & $700-1250$ & $8-10$ & $2-3$ & District & & \\
\hline Quarter & $\begin{array}{l}1800- \\
3000\end{array}$ & $15-20$ & $4-5$ & 2 & Quarter & \\
\hline Area & $\begin{array}{c}3500- \\
5000\end{array}$ & $30-40$ & $8-9$ & 4 & 2 & Area \\
\hline Region & $\begin{array}{c}13500- \\
18000\end{array}$ & $120-160$ & $32-34$ & 16 & 8 & 4 \\
\hline
\end{tabular}

Source: Pour-Mohammadi (2008)

\section{DISCUSSION - IMPLEMENTATION OF STRATEGIES}

The strategic approach to UC policy in Shiraz city was examined through the Master Plan and the HUD Strategies. In order to convert the strategies' goals into actions, the municipalities have been regarded as the most responsible organ at the municipal level. The Master Plan and HUD Strategies both devoted one chapter to "Monitoring Governance for Implementation" comprising duties and responsibilities about implementation of the strategies. The HUD Strategies also include provisions for further financial support and infrastructure. Moreover, the Master Plan needs the local infrastructure strategy to prepare Outline Plans for urban development, transportation, education, and health projects. However, it is noteworthy that in the local infrastructure strategy, there is no commitment for financial support and infrastructure in urban fringe. Therefore, the major focus of local infrastructure strategy is on improving infrastructures and services within urban areas of Shiraz metropolitan city to combat urban sprawl. 
PLANNING MALAYSIA

Sustainable Urban Development

Table 3: Hierarchy of Shiraz urban area centres

\begin{tabular}{|c|c|c|c|}
\hline Centre type & Elements of centre & $\begin{array}{l}\text { Catchment } \\
\text { area } \\
\text { (Meters) }\end{array}$ & $\begin{array}{l}\text { Centre housing } \\
\text { target (expected } \\
\text { average number } \\
\text { of dwellings) }\end{array}$ \\
\hline Major centre & $\begin{array}{l}\text { Major shopping and business centre } \\
\text { serving the region with large } \\
\text { shopping malls, specialist retail, } \\
\text { medical services, office and } \\
\text { residential buildings, council offices }\end{array}$ & 1000 & $13500-18000$ \\
\hline Area centre & $\begin{array}{l}\text { One or two supermarkets, } \\
\text { community facilities, medical } \\
\text { centre, schools; usually a more } \\
\text { residential origin than an } \\
\text { employment destination }\end{array}$ & 800 & $3500-5000$ \\
\hline Quarter centre & $\begin{array}{l}\text { A strip of shops and surrounding } \\
\text { residential area within a } 5 \text { to } 10- \\
\text { minute walk. Contains a small } \\
\text { supermarket, hairdresser, and take-- } \\
\text { away food shops. }\end{array}$ & 600 & $1800-3000$ \\
\hline District centre & $\begin{array}{l}\text { A small strip of shops and adjacent } \\
\text { residential area within a } 5 \text { to } 10- \\
\text { minute walk }\end{array}$ & 400 & $700-1250$ \\
\hline $\begin{array}{l}\text { Neighbourhood } \\
\text { centre }\end{array}$ & $\begin{array}{c}\text { One or a small cluster of shops and } \\
\text { services. }\end{array}$ & 150 & $400-600$ \\
\hline
\end{tabular}

Initially, the municipal council allocates sites in and around city centres close to public transport nodes for higher density housing development. In this regard, the Master Plan needs to allocate higher density housing in different city centres in order to prevent over intensification. This approach provides a more sustainable development of a city centre. Different municipal district has experienced different height of housing block. The sixth municipal district proposed and carried out the merit option of having a maximum of six-storey building height, which became a good model for other municipal districts across Shiraz city (Samzadeh, 2014). The sixth municipality has specifically provided the consideration of the socio-economic and environmental conditions of each site for higher density housing development in their housing strategy. As a result of a comprehensive and collaborative planning to analyse every single selected site for higher density housing, the sixth municipal council emphasized on considering factors such as proximity to public transport systems, healthcare services, education sectors, employment sectors, sports and recreation centres, and shopping centres, and walkability, infrastructure capacity and funding, land ownership patterns, community opposition, and the potential in combination housing form in their development proposal. 
Mozhgan Samzadeh, Zunaibi Abdullah, Saari Omar \& Aniza Abdul Aziz

Sustainable Urban Development through Urban Consolidation Policy in Shiraz, Iran

In addition, the proposed six-storey height limit in the sixth municipal district is considered as the most appropriate option socially and economically with the least threat of negative effect on the neighbouring areas. Likewise, Searle (2004) and Jacobs (1961) also recommend the suitability of five to six storey building height located within walking distance of shops and services. They declared their support for the creation of inner city environments with higher density housing near 'mixed-use' areas to ensure accessibility, vitality, and diversity within the inner city environment. The sixth municipal council has reached a high level of coordination in the implementation of the urban consolidation objectives through the Master Plan and HUD strategies. The sixth municipal council prepared a Key Design Principles along with the housing strategy prior to actual implementation of improvement to identify sites.

\section{CONCLUSION}

This paper tries to encourage focused research on urban sprawl, which is rapidly spreading in Shiraz city. As discussed the common responsible factors of urban sprawl were population and per capita land consumption growth. UC policy, as the land use aspect of the compact city approach and a universal urban sustainable solution (Birkeland, 2012), tends to increase housing density in established residential areas to improve the long-term sustainability of the city, decrease the demand for Greenfield development, and finally control urban sprawl. The focus of UC policy in Shiraz is on centralizing housing in close proximity to the city centres and transport nodes. The experimental justification of this approach is that shopping centres, medical facilities, recreational facilities, and public transportation, all are easily accessible within city centres. This approach is important from two perspectives:

1. Providing opportunities to improve overall levels of vitality in city centres

2. Restricting the spreading housing across low-density suburbia.

This idea is in accordance with the opinion of Bunker et al. (2002) and Searle (2004), who agree that concentrating housing around the city centres increases accessibility and connectivity within the urban environment. Initially, the housing strategy formed based on zoning opportunities and the potential of lands in each LGA to increase the housing density in Shiraz. The capacity of infrastructures and facilities' availability within different city centres have been considered in urban areas to calculate housing targets as Bunker et al. (2002) state that housing targets should be locally sensitive. Moreover, the importance of providing adequate infrastructure, funding, and services has become more apparent to meet the UC goals. The weak point of the Master Plan is that it is limited to economic and demographic oriented (Samzadeh, 2014). This orientation shows the 'big picture' approach of the Master Plan. Therefore, the 
municipal council is required to prepare a more detailed analysis to recognize the capacity of each service for development. This paper concluded that the housing strategy prepared by the sixth municipal council could successfully pave the way to reach the UC goals by considering the relevant mentioned factors. This paper hopes to stimulate professionals, urban decision-makers, and executive officials to articulate and strengthen the dynamics of management, qualification, and renovation in order to achieve sustainable urban development goals.

\section{REFERENCES}

Angel, S., Sheppard, S., Civco, D. L., Buckley, R., Chabaeva, A., Gitlin, L., Kraley, A., Parent, J. \& Perlin, M. (2005). The Dynamics of Global Urban Expansion. Retrieved from http://sollyangel.com/wp-content/uploads/2013/11/2005-The-Dynamics-of-GlobalUrban-Expansion.pdf.

Birkeland, J. (2012), Design blindness in sustainable development: from closed to open systems design thinking. Journal of Urban Design, 17(2), 163-187.

Brueckner J. K. (2000). Urban sprawl: diagnosis and remedies. International Regional Science Review, 23, 160-171

Brunner, J. \& Cozens, P. (2013). 'Where Have All the Trees Gone?'Urban Consolidation and the Demise of Urban Vegetation: A Case Study from Western Australia. Planning Practice \& Research, 28(2), 231-255.

Bunker, R., Gleeson, B. J., Holloway, D., \& Randolph, B. (2002). The local impacts of compact city_in Sydney. Urban Policy and Research, 20(2), 143-167.

Bunker, R., Gleeson, B. J., Holloway, D., \& Randolph, B. (2007). Progress and Prospect with City of Cities: City Futures Research Centre, University of New South Wales.

Burchell, R. W., Shad N. A., Listokin, D., Phillips, H., Down, A., Seskin, S., Davis, J., Moore, T., Helton, D. \& Gall, M. (1998). The cost of sprawl-revisited. Report 39, Transit Cooperative Research program (TCRP) Transportation Research Board, National Research Board, National Research Council, Washington, DC, pp 83-125

Burdack, J. (2002). New economic poles in the periphery of European metropolitan areas. 42nd Congress of the European Regional Science Association (ERSA).

Buxton, M. \& Tieman, G. (2005). Patterns of compact city in Melbourne: planning policy and the growth of medium density housing. Urban Policy and Research, 32(2), 137-157.

Daramola, A. \& Ibem, E. O. (2010). Urban environmental problems in Nigeria: implications for sustainable development. Journal of Sustainable Development in Africa, 12(1), 124-144.

Downs, A. (1999). How America's cities are growing: the big picture. Brookings Review, 16, 8-12.

Ewing, R. (1997). Is Los Angeles-style sprawl desirable? Journal of American Planning Association, 63, 107-126.

Gray, R., Gleeson, B. \& Burke, M. (2010). Urban consolidation, household greenhouse emissions and the role of planning. Urban Policy and Research, 28(3), 335-346.

Jacobs, J. (1961). The death and life of great american cities. New York: Random House.

Jaeger, J. A. \& Schwick, C. (2014). "Improving the measurement of urban sprawl: Weighted Urban Proliferation (WUP) and its application to Switzerland." Ecological Indicators 38: 294 308

Johnson, M. P. (2001). Environmental impacts of urban sprawl: a survey of the literature and proposed research agenda. Environment and Planning A, 33, 717-735.

Lerner, D. \& Lasswell, H. D. (1951). The Policy Sciences: Recent Developments in Scope and Method. Stanford: Stanford University Press.

Mahdian, Y. (2008). City Planning and Management. Gozaresh monthly magazine 92. Shiraz Municipality, Iran. 
Mozhgan Samzadeh, Zunaibi Abdullah, Saari Omar \& Aniza Abdul Aziz

Sustainable Urban Development through Urban Consolidation Policy in Shiraz, Iran

Malenic, D. \& Han, S. S. (2015). Urban Consolidation in Melbourne: a Case Study of the Monash Employment Cluster. http://apo.org.au/node/63340.

Movahed, K. (2008). Discerning sprawl factors of Shiraz city and how to make it livable. 44th ISOCARP Congress 2008.

O'Connor, K., Darby, A. \& Rapson, V. (1995). The great mistake: compact policy in Melbourne and Sydney (Vol. 3): People and Place. Monash University, Centre for Population and Urban Research. Clayton, Vic.

Oladunjoye, A. O. (2005). Nigeria: Implementation of the Sustainable Cities Programme in Nigeria. Sustainable Cities Programme. Localizing Agenda 21 Programme. United Nations Programme for Human Settlements. (UN-HABITAT).United Nations Environment Programme (UNEP). Havana, Cuba. [Online] Available: www.unhabitat.org/scp - http://ww w.unhabitat.org/la21.

Pour-Mohammadi, M. R. (2008): Urban land-use planning. The Organization of Humanities Books Research and Publication of Universities. Tehran university.

Samzadeh, M. (2014). Urban Consolidation In The Context Of The 6th Municipality Of Shiraz, Iran. Department of Architecture, University of Malaya. Master: 145.

Sarvestani, M. S., Ibrahim, A. L.; \& Kanaroglou, P. (2011). Three decades of urban growth in the city of Shiraz, Iran: A remote sensing and geographic information systems application. Cities, 28(4), 320-329.

Searle, G. (2004). The limits to urban consolidation: a framework to assessing limits. Australian Planner 41(1), 42-48.

Seto, K. C., Güneralp, B. \& Hutyra, L. R. (2012). Global forecasts of urban expansion to 2030 and direct impacts on biodiversity and carbon pools. Proceedings of the National Academy of Sciences, 109(40), 16083-16088.

Smith, D. (1997). Third world cities—sustainable urban development III—basic needs and urban rights. Urban Studies, 34(5-6), 797-823.

UNCHS (2007). Urbanization: A Turning Point in History. Global Report on Urbanization [Online] Available: www.unhabitat.org.

UNFPA (2007). State of the World Population 2007, Unleashing the Potential of Urban Growth. New York: United Nations Population Fund.

UN-Habitat, (2007). Milestones in the evolution of human settlements policies.1976-2006. State of the world cities. Report 2006/2007. The MDGs and urban sustainability. 30years of shaping the Habitat Agenda. U.K.: Earthscan.

United Nations. (2004). World population policies 2003. New York: United Nations.

United Nations Department of Public Information (UNDPI). (2008). Achieving the Millennium Development Goals in Africa. Recommendations of the MDG Steering Group. [Online] Available: http;//www.mdgafrica.org. pdf.

United Nations Population Fund (UNFPA) (2007). State of the world population 2007 - Unleashing the Potential of Urban Growth, New York.

\section{GOVERNMENTAL DOCUMENTS}

1. Strategic Plan of Metropolitan (Master Plan Development, 2007); Architecture and Urban Planning Consulting Engineers of Shar-O-Khaneh (2007). The Review of Master Plan of Shiraz. Shiraz municipality (Urban Planning and Architecture Department). Shiraz, Iran, Shiraz municipality.

2. Management and Urban Planning documents (MPO, 2007)

3. Regional Government Strategy (HUD Strategies, 2008).

4. Local Municipal Council Strategy (Housing Strategy, 2008).

5. The internal magazines published by the local governmental organizations, such as Gozaresh. 